\title{
Strengthening School-Family-Community Engagement Through Community Dialogues
}

\author{
Amy L. Cook, PhD \\ University of Massachusetts Boston
}

\author{
Alveena Shah \\ YWCA Boston
}

\section{Lauren Brodsky}

Laura J. Morizio

\section{University of Massachusetts Boston}

\begin{abstract}
Open communication among school community stakeholders strengthens collaboration and facilitates school transformation. Meaningful parent engagement through two-way conversations supports shared decision-making and developing a shared vision for change. We document the implementation and outcomes of community dialogues on race and ethnicity conducted with a group of 11 school and community members, including parents, caretakers, community professionals, and a teacher. Two rounds of semi-structured interviews with participants were conducted and analyzed using qualitative content analysis to explore outcomes of community dialogues. Critical race theory in education guided the community dialogues implementation and qualitative analyses. Findings illuminate participant appreciation for sharing narratives, becoming aware of cultural differences, and raising critical awareness to mobilize community change. Implications of school community dialogues on educational outcomes and counseling practice are also described.
\end{abstract}

Keywords: community dialogues, partnerships, school transformation, community, critical race theory 
Journal for Social Action in Counseling and Psychology

Volume 9, Number 1, Summer 2017

Community Dialogues - Cook et al. 10

\section{Introduction}

Racial and ethnic achievement gaps persist among K-12 students (Bailey \& Bradbury-Bailey, 2010; Cook, Pérusse, \& Rojas, 2012). Children living in poverty are also at high risk for poor outcomes in school performance (Elias \& Haynes, 2008). Barriers to academic achievement are often perpetuated through a school's culture, where educators may inadvertently engage in educational practices that sustain racial inequities (Bryan, 2005). Efforts to promote greater equity must be comprehensive (Cook et al., 2012), and researchers in school reform have emphasized close school, family, and community ties as an integral component of that comprehensive approach (Bryk, Sebring, Allensworth, Easton, \& Luppescu, 2010). When implementing changes to improve academic success for students, Steen and Noguera (2010) stressed the need for "an integrated approach that moves beyond merely implementing inschool interventions to involve all school stakeholders," including not just teachers and administrators, but also parents and community members (p. 45).

Successful partnerships between schools, families, and communities require democratic collaboration or shared decision-making (Bryan \& Henry, 2012). Ferlazzo (2011) emphasized the importance of educators encouraging parent engagement in place of parent involvement. This type of engagement is understood as parents contributing and taking action in the decisionmaking process (engaged), rather than telling parents what to do (involved). Meaningful schoolfamily connections have been associated with improved academic outcomes, including higher grades and test scores, better attendance, and positive behavior (González \& Jackson, 2013; Lee \& Shute, 2010; Zhang, Hsu, Kwok, Benz, \& Bowman-Perrott, 2011). More specifically, González and Jackson (2013) found that shared parent engagement in decision making and educator efforts to promote volunteering and open communication were related to positive year-end data on mathematics and reading achievement among kindergarteners.

School personnel have recognized the need to engage parents and caretakers as true educational partners (Bryan \& Henry, 2012; Yull, Blitz, Thompson, \& Murray, 2014). However, caretakers from low-income and minority backgrounds may experience barriers to engagement that extend beyond work and childcare demands, including discomfort in communicating with school personnel and feeling marginalized (Reece, Staudt, \& Ogle, 2013; Yull et al., 2014). To facilitate meaningful parent engagement, parents must have the opportunity to share their stories and engage in two-way conversations with educators, practices that are often insufficiently encouraged in urban school settings (Ferlazzo \& Hammond, 2009). Open dialogues create opportunities for learning and change and instill a sense of trust in schools, which are necessary precursors to meaningful parent engagement (Price-Mitchell, 2009). This type of communication sets the foundation for strengthening school-family-community partnerships that are guided by a shared vision and represent diverse student needs (Bryan \& Henry, 2012).

One way to facilitate open dialogue between parents or caretakers and school stakeholders is through conducting community dialogues. Community dialogues are intergroup conversations where individuals from different racial, ethnic and cultural groups meet to talk openly in a safe and structured environment about personal experiences with race and discuss ways to address 
race relations in the community (Dessel \& Rogge, 2008; Walsh, 2007). Through facilitating intergroup contact, participants develop increased self-awareness, attitude change, perspective taking, and reduction in bias (Dessel \& Rogge, 2008). Community dialogues employ a "democratic process that acknowledges and respects all parties, creates a context that reinforces the notion that change is possible, and transforms relationships toward positive social change" (Dessel, Rogge, \& Garlington, 2006, p. 304).

Counselors and psychologists are uniquely positioned to conduct or coordinate implementation of school community dialogues given their expertise in consultation and partnering with families and community members (Bryan \& Holcomb-McCoy, 2007; Mellin, Belknap, Brodie, \& Sholes, 2015). They are also charged with strengthening school-family-community partnerships (Bryan \& Henry, 2012). Collaboratively engaging families in children's education is one way to achieve these partnerships. Community dialogues offer the opportunity to strengthen collaboration where families can openly communicate with school and community stakeholders to collectively resolve pressing problems. The present study describes the implementation and outcomes of school community dialogues, as well as explores implications for youth development and counseling practice.

\section{Theoretical Framework}

Community dialogues are based on the premise that participants from diverse racial and ethnic backgrounds can create shared meaning and engage in collective action (Hammack \& Pilecki, 2015). To achieve collective agency, participants must first develop a critical awareness related to experiences of race, racism, and power (Delgado \& Stefancic, 2012; Yull et al., 2014). Applications of critical race theory in education (CRTE) characterize community dialogues and incorporate five basic tenets to inform implementation (Delgado \& Stefancic, 2012; Solorzano, 1997). The first tenet is based upon the premise that racism is pervasive and permanent, while recognizing the intersectionality of race and racism with other forms of oppression, including socioeconomic factors, gender, and other identities. Emphasis is placed on understanding how intersections of people's identity (e.g., race, sex, class, national origin, language preference, and sexual orientation) combine to impact experiences in school communities.

The second tenet challenges dominant ideologies by dismantling practices of colorblindness and race neutrality that dominate educational discourse. Structural determinism inherent in educational agendas makes redressing wrongdoings challenging due to ingrained and widely accepted institutional processes that maintain the status quo (e.g., institutional racism; Delgado $\&$ Stefancic, 2012). Through participation in community dialogues, participants develop greater understanding related to how a colorblind agenda has marginalized communities of color (Yull et al., 2014). A central focus of community dialogues includes becoming aware of structural racism and the tendency for employing deficit-based perspectives to justify racial disparities in education. The third tenet emphasizes a commitment to social justice to eliminate racism and empower communities of color. The fourth tenet appreciates the value of experiential knowledge, such as storytelling, as essential to understanding experiences related to racism and oppression. In this way, community dialogues encourage a race conscious approach to 
Journal for Social Action in Counseling and Psychology

Volume 9, Number 1, Summer 2017

Community Dialogues - Cook et al. 12

transformation (Delgado \& Stefancic, 2012), such that increased awareness of different life trajectories of individuals based on race and racism mobilizes participants to join as a community and develop a shared vision and action plan for change. The fifth tenet focuses on the need for taking a historical and interdisciplinary approach to understand dynamics of power, privilege, and oppression in working toward the elimination of racism in education. Through applying this framework of CRTE, participants are encouraged to share experiences related to race, racism, oppression, and privilege. An increased understanding of power asymmetries facilitates the development of shared action plans that empower communities of color (Dessel et al., 2006).

\section{Purpose Statement}

Outcomes of community dialogues have facilitated personal and social change in community and non-for-profit settings (Dessel et al., 2006). In a study that examined youth intergroup dialogues among high school students, Nagda, McCoy, and Barrett (2006) found improved respect and a reduction in conflict within the participating schools. Ippolito (2010) also examined the impact of holding informal conversations among diverse groups of minority parents within a school district and found that parents appreciated feeling heard and being given the opportunity to call attention to barriers that previously prevented meaningful engagement. Despite these positive findings, outcomes of school-based community dialogues conducted with both parents and educators in elementary urban school settings have not yet been examined. Considering the importance of meaningful parent engagement (Bryan \& Henry, 2012; González \& Jackson, 2013), coupled with limitations of prior research, exploring the potential impact of community dialogues on strengthening school-family-community engagement is warranted.

Community dialogues focus on dismantling racial and cultural barriers that may preclude shared collaboration and decision-making between school personnel and community stakeholders (Dessel \& Rogge, 2008). Dialogues are purported to strengthen partnerships between school personnel, families, and community members, but it is unclear how they may impact parents and educators' comfort level and willingness to seek shared engagement. Thus, we sought to explore how participating in community dialogues may help to break down barriers to schoolfamily engagement and promote shared collaboration and decision making among school community stakeholders. The present study explored the impact of participating in community dialogues using Qualitative Content Analysis (QCA, Schreier, 2012). CRTE served as a guiding framework of analysis to identify themes associated with participants' experiences of race, racism, and dynamics of power in the school community, as well as understand how engagement in community dialogues may empower participants to take action.

\section{Method}

\section{Community Dialogues Curriculum Delivery}

Community dialogues were conducted over five weeks, with a diverse group of school and community participants, consisting of two-hour sessions, during the middle of the school year. A 
Journal for Social Action in Counseling and Psychology

Volume 9, Number 1, Summer 2017

Community Dialogues - Cook et al. 13

YWCA program manager who is trained in facilitating intergroup conversations led the community dialogues sessions in collaboration with a faculty researcher who served as a translator and participant. Dialogues participants came together to engage in dialogue on topics pertaining to experiences of race, racism, and power dynamics in the school community. Sessions were delivered following a curriculum that included pre-selected activities and discussion prompts with the following objectives: (a) Gain understandings of racial, ethnic, and cultural commonalities and differences; (b) Enhance the ability to communicate and appreciate multiple perspectives; (c) Begin to overcome barriers to building relationships and alliances across difference; (d) Share stories of how racial and ethnic identities have impacted the lives of participants; (e) Explore participants' shared vision for their school community; and (f) Create a specific action plan outlining how participants will pursue their vision.

Table 1 Community Dialogues on Race and Ethnicity Foci and Activities

\begin{tabular}{|c|c|c|c|}
\hline Session & Opening & Main Activity & Wrap Up \\
\hline 1 & $\begin{array}{l}\text { Introductions; ground } \\
\text { rules and } \\
\text { agreements; overview } \\
\text { of dialogue } \\
\text { objectives }\end{array}$ & $\begin{array}{l}\text { Who Am I? Activity to share } \\
\text { and reflect on participant } \\
\text { backgrounds }\end{array}$ & $\begin{array}{l}\text { Summarize new } \\
\text { understandings }\end{array}$ \\
\hline 2 & $\begin{array}{l}\text { Review of } \\
\text { agreements; opening } \\
\text { conversations }\end{array}$ & $\begin{array}{l}\text { Opportunity Walk to promote } \\
\text { awareness of experiences } \\
\text { related to race and racism }\end{array}$ & $\begin{array}{l}\text { Reflection and } \\
\text { closing remarks }\end{array}$ \\
\hline 3 & $\begin{array}{l}\text { Brief review of } \\
\text { agreements; opening } \\
\text { conversations }\end{array}$ & $\begin{array}{l}\text { Caucuses by race and ethnicity } \\
\text { to share most cherished } \\
\text { aspects and challenges of } \\
\text { membership with a particular } \\
\text { racial/ethnic group. Key } \\
\text { understandings from caucuses } \\
\text { are then shared with the larger } \\
\text { group. }\end{array}$ & $\begin{array}{l}\text { Reflection and } \\
\text { closing remarks }\end{array}$ \\
\hline 4 & $\begin{array}{l}\text { Opening } \\
\text { conversations; } \\
\text { identifying how } \\
\text { dynamics of race } \\
\text { impact school } \\
\text { community }\end{array}$ & $\begin{array}{l}\text { Creating action plan through a } \\
\text { shared vision. Participants } \\
\text { explore and envision a school } \\
\text { community with divisions } \\
\text { based on race/ethnicity } \\
\text { dismantled. }\end{array}$ & $\begin{array}{l}\text { Reflection and } \\
\text { closing remarks }\end{array}$ \\
\hline
\end{tabular}


Journal for Social Action in Counseling and Psychology

Volume 9, Number 1, Summer 2017

Community Dialogues - Cook et al. 14

\begin{tabular}{|c|c|c|}
\hline $\begin{array}{l}\text { Opening } \\
\text { conversations }\end{array}$ & $\begin{array}{l}\text { Explore barriers and supports } \\
\text { for deepening understandings. } \\
\text { Next steps for taking action } \\
\text { are identified, including } \\
\text { identifying spheres of } \\
\text { influence and power. }\end{array}$ & $\begin{array}{l}\text { Closing and } \\
\text { termination with } \\
\text { focus on identifying } \\
\text { next steps to } \\
\text { implement vision for } \\
\text { change }\end{array}$ \\
\hline
\end{tabular}

Table 1 describes the community dialogues curriculum delivered across five sessions. During session one, participants began sharing through introductions. Ground rules and agreements were discussed and identified, and an overview of dialogue objectives was provided. This was followed by an activity, called, "Who Am I?" during which participants reflected on and shared about who they are, their identities, and cultural backgrounds. Session one ended with a brief closing activity to summarize new understandings. Session two started with a review of agreements and opening conversations. Participants then engaged in an activity called the opportunity walk to promote awareness of how one's race and ethnicity enhance and impede individuals' experiences through reflection and discussion. Session three began with a brief review of agreements and opening conversations. The main activity included forming caucuses (or small groups) by race and ethnicity to identify and communicate the most cherished aspects and challenges to being a member of a particular racial and ethnic group. Key understandings and experiences from caucuses were then shared with the larger group for further reflection and closing. Session four began with opening conversations and identifying how dynamics of race impact the school community. The focus of dialogues shifted toward developing a shared vision and action plan. Through this process, participants explored what the school community would look like if divisions, based on race and ethnicity, were to break down. Session five started with opening conversations. Participants engaged in dialogue to explore barriers and supports for deepening understandings and taking action. Next steps for taking action in the school and community were discussed, including identifying spheres of influence and power as individuals and as a group. Through closing and termination, participants identified steps for implementing their vision and action plan to address race-related issues affecting their school.

\section{Research Team}

The research team was formed as a partnership between the YWCA, a community-based organization, and a higher education institution. Despite a history of collaboration between the institutions and faculty researchers, there were no pre-existing relationships between the school personnel and the YWCA staff. The YWCA partners included two women of color: a program evaluator and a racial justice program manager of community dialogues. The university partners included three White women, a faculty researcher, two doctoral psychology students, and one Latina, bilingual counseling student. The faculty researcher participated in dialogues sessions as a participant, Spanish-English interpreter, and interviewer. Graduate students collaborated on the project to assist with data analyses. 
Both the YWCA and the university uphold social justice missions. Accordingly, the team came together in support of the shared vision to work toward eliminating racism and promoting educational justice for historically disadvantaged youth and families. Through our shared goals and vision, we endeavored to work together to empower communities with a focus on democratic collaboration (Mischen \& Sinclair, 2009), while simultaneously seeking to challenge traditional hierarchies of knowledge and power (Glass \& Newman, 2015). This meant recognizing our positions of power and privileged identities as White researchers from a public university and equally valuing the knowledge and expertise of our YWCA community partners and community stakeholders from diverse racial and ethnic backgrounds.

\section{Participants}

Participants included a racially and ethnically diverse group of parents and caretakers, community-based professionals, and a teacher, all of whom had a vested interest in the local $\mathrm{K}-5$ elementary school. Eighteen individuals signed up to participate, and 11 attended at least three of the five community dialogues sessions. Of the 11 community dialogues participants, nine engaged in post interviews and completed demographic questionnaires and seven completed program evaluation surveys. Of the nine participants, there were six parents or caretakers, one teacher, one staff from the neighboring after school program, and one staff of the neighboring resident services. Of the parents and caretakers, four reported race and ethnicity as African American and two identified as Dominican. Parents and caretakers reported educational history as ranging from having completed high school to two to four years of college, and household income ranging from less than $\$ 15,000$ per year to $\$ 45,000$. Reported race and ethnicity of the three community-based professionals and teacher was Mexican, biracial (Asian Pacific Islander/White), and White, respectively. Reported educational history ranged from four to six years of college, and household income ranged from $\$ 40,000$ to $\$ 60,000$.

\section{Study Site}

The community dialogues were conducted at the public K-5 school's neighboring after school program, located within an urban setting in the Northeastern U.S. The 2015 school report card reported serving 524 students, of whom $88 \%$ were from low-income households and $42 \%$ were identified as English Language Learners. Reported racial and ethnic backgrounds of students included 59\% Latino, 26.5\% African American, 8\% Asian or Pacific Islander, 4\% White, 2\% multiracial, and .2\% Native American. One year prior to conducting the community dialogues, the school was placed under state receivership due to declining state test scores. The process of state receivership resulted in complete school restructure, including dismantling its SpanishEnglish dual language program, lengthening the school day, and laying off all teachers and administrators. As changes occurred, parents were not included in decision-making, which contributed to a sense of mistrust (Taylor, 2013). During school restructure, community partners, including university faculty and staff, local housing staff, and after school personnel, met together with school administrators and identified the need to improve collaborations between school and community organizations, strengthen existing partnership activities, and engage in community-engaged research to advance youth development. To improve lines of communication, community stakeholders identified partnering with the YWCA to conduct a five- 
Journal for Social Action in Counseling and Psychology

Volume 9, Number 1, Summer 2017

Community Dialogues - Cook et al. 16

session series of community dialogues on race and ethnicity among a culturally diverse group of school personnel, parents, and community members. Dialogues were identified to create opportunities for change and restore the community's sense of trust.

\section{Procedure}

Approval to recruit participants, conduct community dialogues, and examine outcomes was obtained by the university's Institutional Review Board. Purposive sampling was used to recruit participants inclusive and representative of the diverse student and school community population. Eligible participants included parents, caretakers, teachers, administrators, school staff, and community-based professionals in the community. The counselor and director of the after-school program through providing an informational flyer, in Spanish and English, conducted recruitment. Eighteen participants agreed to engage in the community dialogues sessions and follow up interviews. All participants were informed participation was completely voluntary and they could later withdraw at any time, including declining to partake in post interviews. Of the 18 participants, seven withdrew after attending one session and were not included in data analyses. Eleven participants attended three or more community dialogues sessions, and nine participants engaged in post interviews.

\section{Measure}

\section{Program evaluation survey}

A post-survey of participants' experience engaging in the community dialogues included five items on a six-point Likert-type scale, ranging from strongly disagree to strongly agree. Participants completed the survey at the end of the last dialogues session. Questions included: (a) The dialogues aided my understanding of race and ethnicity; (b) I heard new perspectives or views on race and ethnicity from members of the dialogues; (c) I believe that my school community's participation in the dialogues will have a positive impact; (d) I believe that the action plan that was developed will have a positive impact on the community; and (e) I met most or all my personal goals through my participation in the dialogues.

\section{Interviews}

Semi-structured interviews were conducted twice, at one month and six months post participation in the community dialogues. Interviews included 12 main questions with corresponding follow up questions, using CRTE (Delgado \& Stefancic, 2012; Solorzano, 1997) as a guiding framework to appreciate parents, caretakers, and school stakeholders' perceptions related to school-community engagement and taking action for positive change. Sample interview questions included: (a) Please describe your comfort level in talking with teachers or parents from the school community. What has increased your sense of comfort? (b) Please describe some of the relationships you have made with teachers or families, particularly those who are culturally different from you. (c) What ideas do you have for improving the school and children's experiences? What role would you want to take in making these changes? (d) Since completing the dialogues, have you been able to take action in promoting racial equity at the school? Please describe. If not, please describe any barriers to taking action. (e) Do you think your action efforts are making an impact? Please describe. If not, what is standing in the way? 
Journal for Social Action in Counseling and Psychology

Volume 9, Number 1, Summer 2017

Community Dialogues - Cook et al. 17

And, what would help to implement your action plan? (f) Please describe your engagement with the school or parents. Has it changed in any way since engaging in the dialogues?

\section{Data Analysis}

A key focus of our work aimed to build community capacity and support local efforts to promote school transformation. We chose QCA to guide the research because of its flexibility and attention to participants' contextual experiences in attributing meaning to texts (Hsieh \& Shannon, 2005; Schreier, 2012). This flexibility fit well with our collaborative research approach by giving voice to marginalized communities and integrating social justice practices in data interpretation and analysis. This meant recognizing the diverse perspectives of researcher input, employing multiple data coders, and facilitating data trustworthiness (Lyons et al., 2013).

Our first step in conducting QCA (Schreier, 2012) involved transcribing recorded interviews and developing a coding structure to inform our understanding of participants' experiences within the school community. This coding structure contained main categories and subcategories, with corresponding codes, related to research hypotheses. To develop our coding structure, we used structural coding, which is a "question-based code" to focus data analyses on specific content areas (Saldaña, 2013, p. 84), following a CRTE framework. Our question-based codes included the following: (a) What themes describe participants' overall experiences in community dialogues? (b) What themes are associated with participants' experiences of race, racism, and power in the school community? (c) How may have engagement in the community dialogues empowered participants to take action? Through this process, we identified subcategories and explored patterns within the transcribed data by employing deductive and inductive approaches. First, we deductively examined transcribed material through applying a framework of CRTE (Delgado \& Stefancic, 2012; Solorzano, 1997) to understand and appreciate participants' experiences, having participated in community dialogues and subsequent engagements within the school community. We then inductively reviewed the data for additional emerging understandings, staying open to the possibility of different ideas and voices.

Next, consistent with structural coding, we tested our coding themes by double-coding the data and checking for consistency (Schreier, 2012). To ensure trustworthiness, three investigators (two of whom were bilingual, Spanish-English speakers), including the faculty researcher and graduate students, followed an iterative consensus process and reviewed transcriptions when differences arose until consensus was reached (Kvale \& Brinkmann, 2009). In this way, triangulation of data consisted of each investigator independently reviewing the data and identifying codes and themes. This process of triangulation allowed for discussion of diverse and similar ways the data were understood. Moreover, follow up interviews at post 6-month participation in the community dialogues were conducted during which the interviewer shared researcher interpretations as an opportunity to reflect on understandings. Lastly, our YWCA research partner conducted an audit review of interpretations to assess whether analyses were reflective and accurately captured participants' experiences. 
Journal for Social Action in Counseling and Psychology

Volume 9, Number 1, Summer 2017

Community Dialogues - Cook et al. 18

\section{Results}

\section{Program Evaluation}

On a scale of one (strongly disagree) to six (strongly agree), participants rated their overall experience engaging in community dialogues as positive $(M=5.4, S D=.32, n=7)$. Table 2 describes the mean ratings on individual survey items.

Table 2 Program Evaluation of Survey

Program Evaluation Survey Mean Scores

$\begin{array}{llll}\text { Survey question } & \text { Mean rating } & S D & N\end{array}$

Group exercises were effective and aided

.53

7

my understanding of race/ethnicity.

I heard new perspectives/views on

.53

7

race/ethnicity from other members of the dialogue.

I believe that my school's participation in the dialogues will have a positive impact.

I believe that the action plan that was

7

developed will have a positive impact on the community.

I met some or all of my personal goals 5.1 .69

7 through my participation in this dialogue.

\section{Coding Frame}

In reviewing transcribed data through a CRTE framework, the research team explored how participating in community dialogues on race and ethnicity might break down barriers to engagement and facilitate school improvement. Through QCA, we built a coding frame (see Table 3) that contained four main categories, each with its own subcategories and corresponding codes. Main categories of themes included: (a) increased awareness, (b) building community, (c) barriers to changing status quo, and (d) taking shared (pro)action. 
Journal for Social Action in Counseling and Psychology

Volume 9, Number 1, Summer 2017

Community Dialogues - Cook et al. 19

Table 3

Coding Frame with Paraphrases from Interviews and Categories

Paraphrases by main categories and subcategory identification

Increased awareness

(Main category)

Awareness of diverse identities (subcategory)

- To just appreciate your own identity. (Building self-identity)

- More aware of not just seeing people how I see them, but also knowing that there is so much more to people. (Awareness of personal biases)

- You need to be open to learning. (Building understanding)

Awareness of racism and power (subcategory)

- People just pretend that it [racism] doesn't exist. (Understanding experiences of blind racism)

- Helped me realize things about the students that I teach, that their parents go through. (Understanding diverse life trajectories due to racism)

- It's nice to hear people say, 'I don't know,' especially when they're in positions of power. (Acknowledging ignorance)

\section{Building community (main category)}

Sharing narratives (subcategory)

- Listening in here what's going on with other people. (Listening and giving space to share)

- I met people and shared things we had in common with them, like what we want for the children. (Finding commonalities)

\section{Crossing comfort zones (subcategory)}

- You get to like understand where people of other, different races are coming from.

\section{Barriers to changing the status quo} (Main category)

Silent divide (subcategory)

- We just sit there like we want to hold everything back. (Growing silence and immobilization)

- No one wanted to hear my whole conversation. (Voices going unheard)

- It's a big leap of faith right now. (Sense of mistrust)

Limited responsiveness (subcategory)

- They never said you can come and sit and talk if you have any problems. (Minimal outreach from school)

- Just being told, 'okay,' and then no follow-up...they never talked to me about what I learned when I went to the community dialogues. (Lack of followthrough)

- It's kind of hard if you have to work. (Unresponsive to logistical needs)

- We parents need to give ourselves the time to come together as a group to say what we need. (Need for parent collaboration and engagement)

Institutional barriers (subcategory)

- I don't blame them personally; I just blame the institution. (School- and policy-based restrictions)

- We can change people's perceptions through dialogue....but I think it's a difficult task. (Racism as systemic obstacle to change) 
Journal for Social Action in Counseling and Psychology

Volume 9, Number 1, Summer 2017

(Appreciating different perspectives)

- How to communicate with someone racially different. (Increasing comfort with different people)

- If you want to talk about race and switching people's perception...it's not an easy one to change. (Challenge of talking openly)

Coming together as a community (subcategory)

- I want this school to improve because it is the school of my community. (School as community)

- It would be nice to meet his friends, hang out in the summer, over the weekend. (Coming together informally)

- There should be more activities so that we can get together, not more meetings. (Events for pleasure)
Community Dialogues - Cook et al. 20

Taking shared (pro)action

(Main category)

Personal empowerment (subcategory)

- I too live here and have a voice and vote. (Determination to take action)

- I will keep fighting until things get better. (Never giving up)

Raising critical awareness (subcategory)

- I have a better understanding and more skills to help others. (Sharing awareness with others)

Mobilizing the community (subcategory)

- That was something we all did because we stood behind each other. (Invoking immediate change)

- It's a forward movement and if we can get more parents aboard. (Maintaining momentum of action)

- This needs to go further... Nothing is going to prove anything in a year. (Longterm vision)

\section{Increased Awareness}

The main theme of increased awareness was identified as it pertained to participants describing greater understanding and appreciation for cultural identity and awareness of issues related to race, racism, and power. Two subcategories of themes emerged within increased awareness: (a) awareness of diverse identities and (b) awareness of racism and power.

\section{Awareness of diverse identities}

Participants, particularly the teacher and staff, expressed greater awareness of their own diverse identities. They also developed awareness of how they perceive others' identities and expressed appreciation for diversity. With respect to building self-identity, one participant talked about the importance of valuing one's identities:

(Jeanne ${ }^{1}$, Staff): To just appreciate your own identity and value it, and I think I'm just coming into this also as a woman, too...I'm a person just like everyone else, but not realizing...it's okay to be proud to be Jewish, for kids to kind of take pride in their own culture and wanting to share those things with us.

\footnotetext{
${ }^{1}$ Pseudonyms are provided for each participant. 
Participants also described how the community dialogues increased awareness of how they perceive others and personal biases. For example, one participant shared how he based people's racial identity on skin color but learned how such assumptions based on visual observations are limiting. This realization helped to facilitate this participant's growth and appreciation for opportunities to dialogue with others:

(Luis, Staff): So, hearing the people's experiences, you know the people that were there, parents, educators, directors of clubs; it was interesting to see how people perceive themselves as maybe not being Black, even though I'm looking at you, and I'm thinking maybe you're Black. But now you're identifying yourself with American Indians...A teacher being there and how she identified herself, so being able to hear and see them through their perceptions of how they perceive themselves. It has made me also a better person. Maybe more aware of having more knowledge of not just seeing people how I see them, but also knowing that there is so much more to people, and you won't get to know them unless you actually have that conversation with them about that.

Similarly, another participant talked about the realization that she used to make assumptions about others:

(Helen, Teacher): I've had to realize that sometimes when I was first teaching, in my younger times, I would sort of assume certain things. So, I think keeping that in mind and understanding that I don't necessarily understand where they're coming from when they say certain things...like, 'Well you would never understand.' They're right, I never will.

To better understand and appreciate diverse identities and different experiences, participants expressed how important it is to try to understand. Helen (teacher) went on to say how important it is to be open to learning about others:

I think if you're going to teach in urban schools in diverse cultures, you need to be open to learning about them. And, you know not it's more than just, 'Oh you don't celebrate Christmas, you celebrate Hanukkah, so we'll celebrate both.' I think it's more than that.

Sara (a parent) also expressed the importance of understanding others, "We try to look beyond your race when you're doing certain things in this world, [but] it's good to know who you are cause if you don't know who you are, you don't know where you come from." Relatedly, Graciela, another parent, expressed appreciation for making connections with parents from diverse cultural backgrounds. "Me gustó porque hice una conexión con todos los padres de diferente razas...Y le digo a la escuela que deben de ayudar hacer eso también." ("I liked that I made a connection with all of the parents from different races...And I tell you that the school should help to do that, too.") 
Journal for Social Action in Counseling and Psychology

Volume 9, Number 1, Summer 2017

Community Dialogues - Cook et al. 22

\section{Awareness of racism and power}

In addition to building awareness of diverse identities, participating in the community dialogues promoted greater awareness of racism and power dynamics, particularly for the teacher and staff. Understanding experiences of "blind" racism was discussed as an important awareness for participants and the greater community. For example, Helen (teacher) shared, "It's almost like blind racism in society today. That people just pretend that it doesn't exist. You know, so I feel like everybody needs to understand that." Luis (staff) emphasized the power that acknowledging "subtle" racism can achieve in building understanding:

I was very surprised by the number of people that felt as there really wasn't that much racism in the world. And I think it's just because we, I don't want to say we, but racism is, in order for it to count as racism, it has to be so overt, and they're always subtle things that happen all the time...I think it was very powerful; it was powerful for me to hear because I hadn't thought of that.

Helen (teacher) also expressed a deeper understanding of individuals' life trajectories due to experiences of race and racism:

It was pretty eye opening, but in a good way...It sort of helped me realize things about the students that I teach, that their parents go through, that impact what the kids go through...How some of the parents are striving to make sure their kids don't go through the same things that they had to go through...Even though we say we're progressive in race, we're really not, as a society. The parents...have to do what they can do...

With respect to understanding dynamics of racism, participants expressed greater awareness of power differentials and privilege. For example, Jessica (a parent) appreciated when a fellow participant acknowledged her ignorance despite her position of power as an educator:

(Jessica, Parent): So that was new for me, but one of the most powerful things was hearing the teacher say 'I acknowledge the fact that I don't know where people are coming from.' Because usually, I feel that teachers that are like, 'Oh, I know where they're coming from, and we don't understand each other, but I know.' And I'm like, 'you don't know exactly what's going on with that kid'...So, I think that it's nice to hear; it's always nice to hear people say, 'I don't know.' Especially when they're in positions of power, and as a teacher, you are in a position of power.

Having participated in community dialogues helped to build a level of comfort in communicating with people from diverse racial and cultural backgrounds. Participants also expressed greater appreciation of diverse identities and awareness of racism and power.

\section{Building Community}

The main theme of building community captured participants' experiences of starting anew to build community through sharing stories, crossing comfort zones, and coming together. Three 
Journal for Social Action in Counseling and Psychology

Volume 9, Number 1, Summer 2017

Community Dialogues - Cook et al. 23

subcategories of themes were identified within the main theme of building community: (a) sharing narratives, (b) crossing comfort zones, and (c) coming together as a community.

\section{Sharing narratives}

In sharing narratives, participants appreciated the opportunity to get to know one another through listening and giving space to share. Donna (a caretaker) shared, "I've never been through anything like that. Listening in here what's going on with other people." Jeanne (staff) similarly shared her experience:

I never participated in anything like that before; it was the first time there was a space created for members of the school community, and for the out of school community, and the residential community, to have a time specifically dedicated to race. We all are usually running around focusing on day-to-day logistics and operations. So for me, I think it took a while to kind of sink in to realize what we were discussing, and it was very kind of comforting to see everyone that came and recognize everyone's investment.

Participants also expressed gratitude for the opportunity to share and socialize with people from the community, with whom they previously had not met. One participant shared the following:

(Leticia, Parent): Compartí con personas de aquí del mismo residencial, con personas que tienen nietos y niños ahí en la escuela, que no me había salido de la casa a socializar con nadie en estos últimos tres años casi que tengo viviendo aquí. Pero ahora conocí personas...que compaginábamos con las cosas que tanto ellos como yo queremos para los niños. A mí me gustó. (I shared with people from the same community, with people who have children and grandchildren here at the school, with whom I hadn't socialized with because I hadn't gone out of the house for almost the last three years since living here. But now I met people and shared things we had in common with them, like what we want for the children. I liked it.)

\section{Crossing comfort zones}

Through sharing narratives, participants crossed comfort zones, permitting appreciation of different perspectives and understanding different life trajectories based on experiences of race and racism. For example, Jill (a caretaker) reflected on the community dialogues: "You get to like understand where people of other, different races are coming from, and, you know, what's important to them that I didn't know of, or get to know different cultures and stuff like that." Similarly, Jeanne (staff) expressed how the dialogues helped build a sense of comfort to connect with different members of the community. "I feel more comfortable, absolutely, talking about issues. Just to have them, to have both parties experience each other in a way where you're sharing something personal, kind of sets a nice basis for future sharing of information." Similarly, Graciela (a parent) appreciated feeling comfortable getting to know people from different backgrounds: "De cómo interactuar más con las diferentes razas y sentirse uno cómodo cuando hablando con alguien." ("How to communicate more with different races and feeling comfortable when talking to someone [that is different].") 
On the other hand, everyone may not readily embrace crossing comfort zones. Luis (staff) expressed the challenge of talking openly about race and racism.

A lot of time, because everybody is busy doing what they have to do...it almost becomes like an extracurricular activity. Especially if you want to talk about race and switching people's perception, and upbringings. I think that's a task that is not an easy one to change. And, it's not something that everybody wants necessarily.

\section{Coming together as a community}

Participants, predominantly parents and caretakers, also identified the school as a critical part of the community and discussed a desire to come together as a community. Graciela (parent) shared how even though her children will be leaving the school to enter a middle school, that the elementary school is still an important part of the community. "Aunque yo me vaya de aquí, yo quiero que esa escuela mejore porque es la escuela de mi comunidad." ("Even though I'm leaving here, I want this school to improve because it is the school of my community.") Sara (parent) shared how important the success is of the school and community. "I'm standing up for that school because I went to that school, and I would love my son's child to go to that school. It was a great school, it's a great community."

Participants talked about ways to build the school community through coming together informally and through school community-wide events. Jill (caretaker) shared the desire to get to know more children from the school. "It would be nice to...meet his friends from school to hang out in the summer or over the weekend." Relatedly, two participants shared a desire for more school-wide events for pleasure and not just meetings. "Yo siento que habría también que hacer actividades, para que nos podamos reunir, no más reuniones, sino que también que hagamos eventos, porque ellos embullan mucho y embullan a los papás." ("I feel there should be more activities, so that we can get together; not more meetings, but also that there are events, so we can have fun together with parents.") Overall, participants talked about how the community dialogues provided the opportunity to build community through sharing narratives and crossing comfort zones. The school has held an important position in the community, and participants expressed the desire to further build that community through coming together.

\section{Barriers to Changing the Status Quo}

Beyond appreciating the sharing of narratives and coming together as a community, all participants identified significant barriers to changing the status quo. Within the main theme of barriers to changing the status quo, three subcategories of themes emerged: (a) silent divide, (b) limited responsiveness, and (c) institutional barriers.

\section{Silent divide}

Participants felt their voices were not heard and felt uncomfortable participating in the school community. Sara (parent) expressed frustration with respect to the growing silent divide between teachers and parents resulting in feelings of immobilization: 
Parents and teachers don't seem to want to comingle with each other, and I don't know if they feel the issue of the school being changed from a public to private school or whatever they want to consider it...more of a charter running school than a public school. I just think there's too much combatery...We used to have a ton of cry out for this school; there used to be, 'Listen, we're coming, we're not having this!' I mean it was like, 'spread the word.' [Now] we just sit there like we want to hold everything back.

A contribution to the growing silent divide seemed to be represented by people's voices going unheard, where participants felt no one was listening. Sara (parent) further shared the following:

The parents, we were all out there rallying, 'Don't close the school!' My son even caught me off guard because he found me on a YouTube video that I was standing up for the school. I was like, 'Listen, don't close it. Merge it, give it old and new, bring it back together; make it fresh.' No one wanted to hear my whole conversation.

Luis (staff) also shared similar frustrations and sense of mistrust, "It's almost like saying 'okay, let's all get together, bring what we need to bring to the school and hopefully it won't fall on deaf ears.' It's a big leap of faith right now." Feeling unheard was identified as a significant barrier to changing the status quo.

\section{Limited responsiveness}

Possibly contributing to the silent divide is the experience of limited responsiveness, identified predominantly by parents and caretakers as a second subcategory of barriers to changing the status quo. Participants discussed experiencing minimal responsiveness from both within the school and the community. For example, Sara (parent) shared how it would be helpful for administrators to extend an invitation to welcome parents into the school:

They never said, 'you know you can come and sit and talk if you have any problems,' or anything; like an invitation, if you need to talk to us. When they introduce at the school, they never put it to that, where you could be comfortable.

Helen (teacher) shared her experience of unresponsiveness through lack of follow-up from administration from her perspective as an educator:

Just being told, 'okay,' and then no follow-up; you know, they never even talked to me about what I learned when I went to the community dialogues. You know, like it's never really been like a discussion. So, it's like, 'Oh you don't care, that's great.' But you know, it's a school. They can't care about this stuff; they have to meet the grades.

Relatedly, Jessica (parent) identified the school as being unresponsive to the logistical needs of parents. "I know they have student council, I mean parent council meetings..., but it's from 5-6. It's kind of hard if you do work." Despite the logistical unresponsiveness, several participants 
appreciated the genuine regard and openness that teachers demonstrated. Jill (caretaker) shared, "They're like very open, and they like to sit and discuss things too... The teachers that I have spoken to, they seem more open. And she always sends notes home..., letting me know what he's accomplishing." Although many participants expressed appreciation for the individualized attention to students, participants voiced the need for greater coordinated efforts to effectively communicate with parents. For example, Sara (parent) shared:

I don't understand what's going on; there's no really like parent organization. They used to have the community meeting to let everyone in the community know what's going on with the school and how we're changing. It's like they really just stopped that when they took over with the new teachers...with the charter school.

In addition to the need for greater responsiveness from the school, participants expressed the need for parents to actively engage in the school. For example, Graciela (parent) shared:

Yo siento que la escuela, lo que más necesitamos es un poquito más de unión entre los mismos padres porque...yo siento que nosotros los papás, que tenemos que darnos tiempo, que tenemos que tratar de unificarnos entre grupo, en decir bueno, me interesa esto y esto, pero tenemos que poner nuestra parte los padres. (I feel that what the school, that we need most is a little more collaboration between parents because...I feel that we parents need to give ourselves the time to come together as a group to say what we need.)

\section{Institutional barriers}

The third subcategory, institutional barriers, was identified within the main theme of barriers to changing the status quo. Participants talked about awareness of policies and practices within the school community and at a societal level that impede transformation. Sara (parent) talked about her perceptions that teachers are restricted in the ability to implement parent suggestions due to school-related pressures and policies that dictate practices.

We will be proactive with you, but I just think that they keep everything so closed up. And they like our ideas, but they don't know how to implement them. That's where my concern is for the teachers. I feel like they see it; they know what's wrong with it; they are afraid to step up to say anything on it, because if they do, they're in fear of their jobs.

Similarly, Helen (teacher) shared her experience as an educator with respect to school- and policy-based restrictions impeding systemic change in the school:

Of course, I mean everything is data driven; it's not their fault. I don't blame them [administrators] personally; I just blame the institution. I think that there is just so much more important things that they need to worry about, that for one reason or another, this just isn't as important. It really kills me because we are an urban school. 
Journal for Social Action in Counseling and Psychology

Volume 9, Number 1, Summer 2017

Community Dialogues - Cook et al. 27

Despite active participation in the community dialogues, Luis (staff) recognized the pervasiveness of racism as a significant systemic and institutional obstacle to change:

I think that there are educators that believe that we can change people's perceptions through dialogue; and you know, getting to know each other on a different level, through conversations, but I think it's a difficult task. I mean it's a systemic disease, especially in America, racism. And it's going to take a long time to get it out.

Although participants expressed a strong desire to take action, with community dialogues igniting a sense of urgency and motivation, participants expressed continued struggles with barriers to changing the status quo. These obstacles to transformation that participants voiced include a growing silent divide, sense of unresponsiveness, and institutional barriers.

\section{Taking Shared (Pro)Action}

The main theme of taking shared (pro)action included three subcategories of themes that emerged: (a) personal empowerment, (b) raising critical awareness, and (c) mobilizing the community. Through engagement in community dialogues, participants expressed an increased desire to act in a way that both promotes active change in the moment and is proactive in anticipation of future needs, problems, and changes.

\section{Personal empowerment}

Many participants, predominantly parents and caretakers, expressed feelings of personal empowerment, having engaged in the community dialogues. For example, Leticia (parent) shared how the dialogues promoted her determination to actively participate on the school council:

Porque yo antes no me expresaba, yo iba a la reunión pero me quedaba callada, pero acá, yo me expresé. Aquí me dieron la oportunidad de expresarme, de ser yo, de decir lo que yo siento, de sacar lo que yo siento. Porque yo también soy de aquí, yo también vivo aquí, también tengo voz y voto, y ellos me dieron la oportunidad de hacer eso. (Because before I didn't express my thoughts; I would go to the meeting and keep quiet, but here I expressed myself. Here, they gave me the opportunity to express myself, to be me, to say what I feel. Because I, too, am from here; I too live here and have a voice and vote; and they gave me the opportunity to do just that.)

Similarly, Graciela (parent) shared how she feels empowered to keep fighting and will never give up. "No me doy por vencida nunca. Seguiré luchando hasta que la cosas mejoren. Esa es mi meta y espero lógralo, es mi objetivo." ("I won't ever give up. I will keep fighting until things get better. This is my goal, and I hope to achieve it.") Jill (caretaker) also talked about her desire to become more active on the parent board. "I decided that I do want to get onto [the] parent board because they do need a lot of things over there, especially now that the principal's gone." 
Journal for Social Action in Counseling and Psychology

Volume 9, Number 1, Summer 2017

Community Dialogues - Cook et al. 28

\section{Raising critical awareness}

In addition to personal empowerment, the theme of raising critical awareness among local community members may serve as a catalyst to promoting broader change within the school. Through participating in community dialogues, participants talked about how they initiated discussions with others to promote critical awareness.

For example, Luis (staff) talked about how he can share his insight with others to raise awareness. "I can let them know that some of the things that they say are inappropriate and not well founded." Similarly, Graciela (parent) shared how the dialogues helped to express herself more clearly with respect to raising others' awareness. "Puedo ayudar a otros para que no se sientan discriminados. De estar más clara después de los diálogos, pues sí. Después de los diálogos he estada más clara. He tenido técnicas mejores para poder ayudar a otros." ("I can help others so they don't feel discriminated against. I have a better understanding and more skills to help others.") Yet, Helen (teacher) talked about how the dialogues helped in the classroom. "It's helped me, like you know, when we tackle things, like race in the classroom, and things like that, I let them be honest. And, I talk about it...I own it." She went on to share about an interaction with a colleague and her attempt to initiate challenging conversations about race:

Colleagues I've definitely had discussions with. I was actually just talking to someone today about race and how it impacts the kid and this and that...I think a lot of people are uncomfortable discussing it because you never want to say the wrong thing.

Leticia (parent) relatedly shared how she tries to raise critical awareness through her interactions with parents in the community. "Yo siento que, con las personas que he hablado, siento como que a mí me entienden, y entienden que hay que intentar cambiar el sistema para bien, para el bien de nuestros hijos." ("I feel that, with the people I have talked to, I feel that they understand me, and they understand that one must try to change the system for the better, for our children.")

\section{Mobilizing the community}

In taking shared (pro)action, the subcategory of mobilizing the community was identified, insofar as participants talked about personal and collaborative leadership efforts to transform the local school community through immediate changes and long-term vision. Sara (parent) shared about a recent event where she and fellow parents came together to invoke immediate change on a pressing issue:

We all came out there; we made this gentleman stop acting this way toward our children on the bus. We all got together and stopped that. That was something we all did because we stood behind each other and did it.

Graciela (parent) also described her collaborative efforts to solve problems in the community. "Lo mío no es montar presión como dicen, tener presión ni nada, sino tratar de resolver los problemas." ("My approach is not to pressure, as they say, or add pressure or anything, but to 
Journal for Social Action in Counseling and Psychology

Volume 9, Number 1, Summer 2017

Community Dialogues - Cook et al. 29

try to resolve problems.") Luis (staff) talked about how the community dialogues "relit the fire...that we need to keep doing that. Because if you let it go, it will let go. It takes a lot of effort for all of us to say, 'Let's meet on a weekly basis." He went on to share how the community dialogues stimulated strong motivation to continue the momentum of present action.:

In terms of changes, just the fact that [the director] called me and said, 'You know I was talking to those parents that were meeting on Thursday, and they want to continue those meetings.' So yes, there is a change, you know, it's a forward movement, and if we can get more parents aboard, and just being on the same page, it's a forward movement.

Jeanne (staff) also expressed the need for the open dialogues to continue beyond the shortterm:

You got to keep this going; this needs to go further. I just hate seeing, and the same thing with education, I hate seeing with programs that just stop for whatever reason, like they haven't proven something. Nothing is going to prove anything in a year. It's not.

Helen (teacher) also shared her vision to making more systemic and longer-term changes: "When we have meetings about what PD's [professional development] we want, just speaking up about how we need these talks, and we need some cultural understanding about what these kids go through."

Overall, participation in the community dialogues encouraged participants to take shared (pro)action through promoting a sense of personal empowerment, raising critical awareness among others, and mobilizing the community.

\section{Discussion}

Through community dialogues on race and ethnicity, parents, caregivers, community providers, and a teacher came together to discuss and rebuild a community inclusive and aware of racial differences and disparities in education. Community dialogues broadened participants' understanding of race and race-related experiences and were conducted within a CRTE framework. CRTE incorporates five main tenets, based on the understanding that racism is pervasive and provides a critical lens toward eliminating racial inequities in education (Solorzano, 1997). Through empowering school community members to share narratives, understand dynamics of power, and create a shared vision, CRTE guided implementation of dialogues, interviews, and analyses. Figure 1 depicts the emerging themes from interviews and corresponding CRTE tenets. 
Figure 1. Depicts central tenets of CRTE shown in the center with circular arrows to indicate that processes of awareness and transformation are ongoing and multidimensional. The outer boxes contain corresponding themes associated with CRTE.

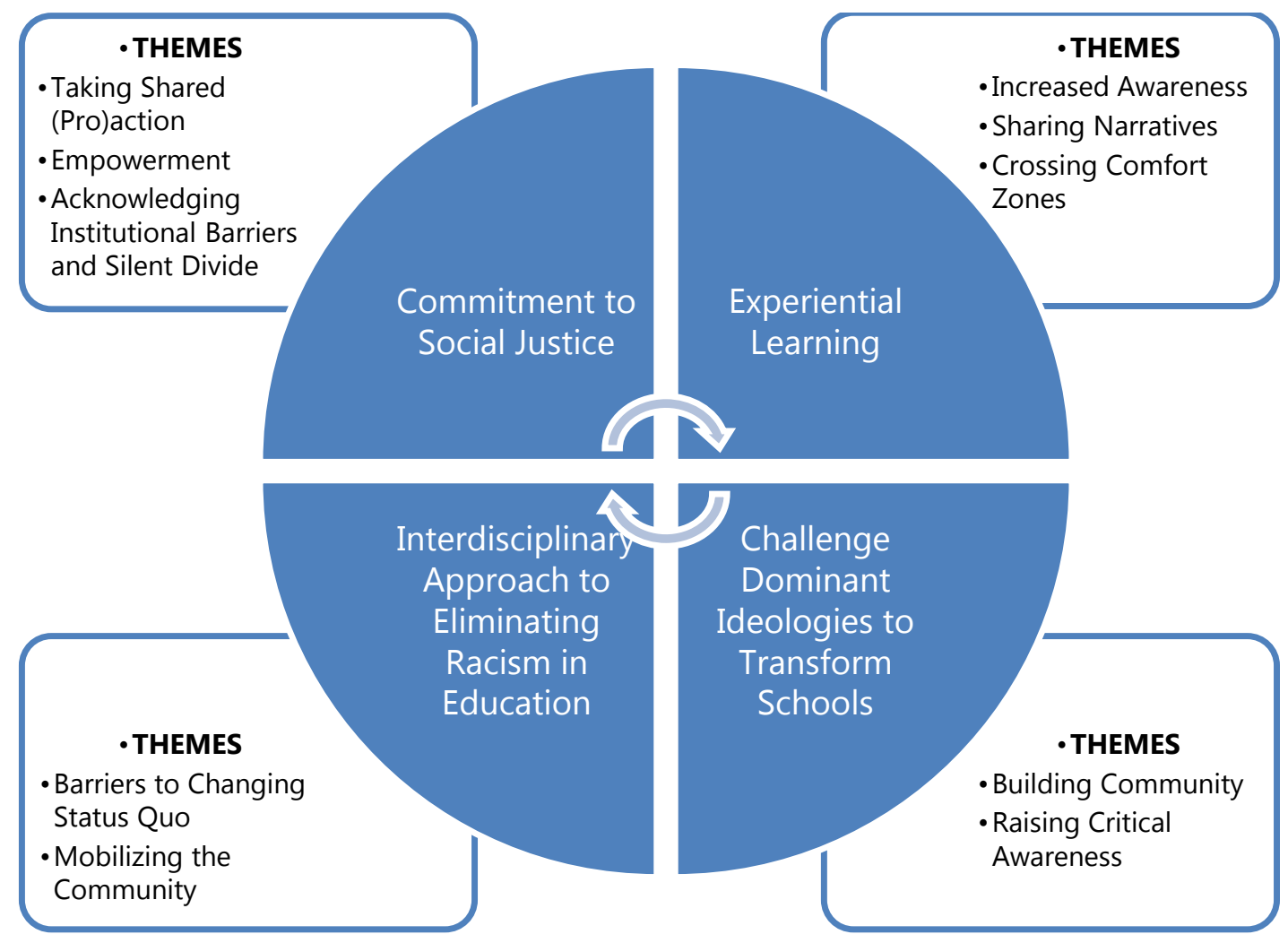

Qualitative content analysis of semi-structured interviews with participants identified, four main themes, including: increased awareness, building community, barriers to changing the status quo, and taking shared (pro)action. Participants expressed appreciation for the opportunity to share narratives that gave space to build awareness of diverse identities and racism and power, particularly among the community staff and teacher. Through crossing comfort zones and coming together as a community, participants took risks to appreciate different perspectives and increase comfort with others. In following CRTE, this type of experiential knowledge is a critical first step to increasing participants' awareness of racism (Delgado \& Stefancic, 2012). Participants, predominantly parents and caretakers, also struggled with promoting change and expressed frustration with the silent divide and limited responsiveness among school and community members. Despite barriers, participants expressed a strong desire to raise critical awareness and mobilize the community to promote change. Participants' determination to transform the school community becomes possible through experiential learning, awareness, and understanding (Solorzano, 1997; Yull et al., 2014). Overall, participating in community dialogues engendered a sense of individual empowerment and collective agency to promote 
Journal for Social Action in Counseling and Psychology

Volume 9, Number 1, Summer 2017

Community Dialogues - Cook et al. 31

change. Participants viewed community dialogues as a positive experience as indicated in exit surveys.

CRTE researchers suggest that parents of color hold an integral role in teaching children strategies to counternarrate experiences of racism (Yull et al., 2014). Creating a space within the school community where parents and school community members can safely and openly share experiences related to race and racism is one way to shift traditional power dynamics and foster greater transparency. Dialogues differ from other forums, such as parent councils and town hall meetings, insofar as dialogues intentionally focus on issues related to race and racism and bring together both parent and educator constituencies. Although facilitating open discussions about race can be challenging, they provide opportunities to work toward promoting racial equity and equality in schools and communities (Rush, 2011). Further, providing opportunities to improve cultural competency and build awareness are key to promoting understanding and facilitating a change in attitudes and educational practices (Cook, Hayden, Gracia, \& Tyrrell, 2015). The community dialogues offered participants, particularly community and teacher providers, the opportunity to build cultural competency and awareness.

It is important to note that many parent participants expressed appreciation for the openness and genuine positive regard that individual teachers demonstrated in regular interactions with families. However, there were concerns that reflected the general perception that parents' voices often go unheard, resulting in limited outreach efforts to families. These experiences of feeling unwelcome or undervalued may represent the challenge that many school administrators, counselors, and other school personnel encounter to form effective school-family partnerships. Considering the complexity of urban communities and diversity of student and family populations, educators may struggle to establish meaningful relationships and effectively communicate with culturally diverse families (Price-Mitchell, 2009). Findings from community dialogues may suggest the possibility for building shared understandings and awareness that facilitate meaningful parent engagement and school-family-community partnerships. Counselors and related mental health professionals hold an integral role in facilitating these types of engagements and partnerships (Bryan \& Henry, 2012).

Relatedly, the themes of building community and feelings of frustration regarding barriers to change may also reflect the overall impact and importance of school culture and climate. Acevedo-Gil (2016) identified a connection between school culture and school climate, exemplified by the intersection of school-wide standards, beliefs, and educator practices that combine to influence climate. Although factors influencing school climate are complex, promoting a reduction in conflict, while simultaneously creating space for alliance building and perspective taking, may contribute toward improving school climate. Researchers examining outcomes of intergroup dialogue have observed significant decreases in conflict in schools and other settings (Abu-Nimer, 1999; Miles \& Kivlighan, 2012; Nagda et al., 2006). Further research is needed to examine relationships between school community dialogues and school climate, considering the potential impact on strengthening school-family-community partnerships. 
Of final note is the importance of maintaining momentum through sustained engagement. One participant shared her frustration of seeing new initiatives discontinued, while expressing the need for community dialogues to become a regular part of school-community practices. This call for sustained engagement suggests the need for researchers to be fully engaged throughout program implementation, evaluation, and beyond. Coulter (2002) argued that researchers share the responsibility of jointly taking action within aggrieved communities to effect transformative change. Bryan and Henry (2012) also described the challenge inherent to maintaining momentum that sustains new partnership initiatives, suggesting counselors and practitioners to engage in reflection and celebrate progress. Interviews conducted with community dialogues participants provided an opportunity to reflect and collaboratively move forward, following a joint collaborative approach to action research. Our next steps as researchers involve continued collaboration with the YWCA to examine longitudinal outcomes of the dialogues work.

\section{Limitations}

Although community dialogues aimed to create a trusting environment in which all participants felt comfortable sharing stories and personal experiences with race and racism, a language barrier may have prevented some of the participants from fully contributing. An interpreter was present during each community dialogue session to ensure all participants could understand and participate in discussions. Although the interpreter, who was a locally known professional and researcher, functioned to bring the community together, it is possible that some of the participants may have felt discomfort. Addressing this discomfort is necessary for two-way conversations to take place and ensure a trusting environment (Ferlazzo \& Hammond, 2009). A cultural broker is a helpful way to facilitate greater comfort and open communication between school personnel and community members (Bryan \& Henry, 2012).

Another limitation is the small sample size that precludes understanding the potential impact of dialogues on school climate in general. Findings are limited to the school and local community level. Further, low teacher and school administrator representation is an additional limitation despite the participation of local community-based professionals. While dialogue leaders made efforts to accommodate teacher and administrator schedules, including holding dialogues in the evening and providing dinner, only one teacher participated. Low teacher and administrator turnout may have been due to recent structural and administrative changes subsequent to the school coming under state receivership. These changes resulted in longer school days, possibly making it difficult to attend community dialogue sessions after a long school day. They may also have contributed to a sense of unease or unwillingness to participate. Greater teacher participation could have catalyzed further conversations at the elementary school in advocating for identified needs with school administration. Low teacher and administrator turnout may have contributed to the sense of low responsiveness and growing silent divide that were perceived as barriers to changing the status quo. The low teacher and administrator turnout may also explain the high variability of expectations that community dialogues participation can make a positive impact $(M=5 ; S D=1.83$; see Table 2$)$. Despite these limitations, community dialogues contributed to themes of change, including raising critical awareness and mobilizing the 
Journal for Social Action in Counseling and Psychology

Volume 9, Number 1, Summer 2017

Community Dialogues - Cook et al. 33

community that may propel parent and community members forward with a shared vision within their school.

\section{Conclusion and Implications}

There is a growing population of students of color across the United States, and consequently achievement gaps between racial and ethnic groups will carry greater social and economic impact on communities (Center for Public Education, 2012). Schools can be better positioned to address racial disparities in educational attainment through support from parents and communities (Bryan \& Henry, 2012). Community dialogues offer the possibility to strengthen school-family connections that are needed to foster meaningful parent and educator communication, improve school climate, and promote positive youth development. In the present study, participants expressed appreciation for building new relationships, becoming aware of differences, and developing a shared vision to impact change as a result of engagement in community dialogues. Participating in intergroup dialogue, particularly within diverse demographic locations, can improve school-community collaboration. Counselors and psychologists serve an integral role in facilitating school community dialogues and making effective school-family-community partnerships possible.

\section{Author Contact Information}

Please address correspondence concerning this article to Amy Cook, Department of Counseling and School Psychology, College of Education and Human Development, 100 Morrissey Blvd., University of Massachusetts Boston, Boston, MA 02125. Email: amy.cook@umb.edu; Phone: 617-287-7585.

\section{Acknowledgment}

We would like to acknowledge Paula Lima, Queenette Santos, Santi Dewa Ayu, Natalia Martinez, Veronica Alache, and Angelica Rivera for their assistance throughout program implementation. In addition, program planning and implementation was made possible through the Endowed Faculty Career Development Award, sponsored by the University of Massachusetts Boston.

\section{References}

Abu-Nimer, M. (1999). Dialogue, conflict resolution, and change: Arab-Jewish encounters in Israel. Albany: SUNY Press.

Acevedo-Gil, N. (2016). Critical race case study on college choice: Racialization in school culture and climate. In Conchas, G. \& Hinga, B., M. Cracks in the schoolyard: Confronting Latino educational inequality. New York, NY: Teacher's College Press.

Bailey, D. F., \& Bradbury-Bailey, M. E. (2010). Empowered youth programs: Partnerships for enhancing postsecondary outcomes of African American adolescents. Professional School Counseling, 14, 64-74. doi:10.5330/prsc.14.1.0vk554458027081n 
Journal for Social Action in Counseling and Psychology

Volume 9, Number 1, Summer 2017

Community Dialogues - Cook et al. 34

Bryan, J. (2005). Fostering educational resilience and achievement in urban schools through school-family-community partnerships. Professional School Counseling, 8(3), 219-228. Retrieved from https://www.schoolcounselor.org/school-counselorsmembers/publications/professional-school-counseling-journal

Bryan, J., \& Henry, L. (2012). A model for building school-family-community partnerships: Principles and process. Journal of Counseling and Development, 90, 408-420. doi:10.1002/j.1556-6676.2012.00052.x

Bryan, J., \& Holcomb-McCoy, C. (2007). An examination of school counselor involvement in school-family-community partnerships. Professional School Counseling, 10, 441-454. doi:10.5330/prsc.10.5.f266j386342r57g6

Bryk, A. S., Sebring, P. B., Allensworth, E., Easton, J. Q., \& Luppescu, S. (2010). Organizing schools for improvement. Chicago, IL: University of Chicago Press.

Center for Public Education. (2012). The United States of education: The changing demographics of the United States and their schools. Retrieved from http://www.centerforpubliceducation.org/You-May-Also-Be-Interested-In-landing-pagelevel/Organizing-a-School-YMABI/The-United-States-of-education-The-changingdemographics-of-the-United-States-and-their-schools.html

Cook, A. L., Hayden, L. A., Gracia, R., \& Tyrrell, R. (2015). Exploring outcomes of a targeted supervisory training curriculum on developing multicultural competency and social justice advocacy. Counseling Outcome Research and Evaluation, 6, 126-140. doi:10.1177/2150137815594201

Cook, A. L., Pérusse, R., \& Rojas, E. D. (2012). Increasing academic achievement and collegegoing rates for Latina/o English Language Learners: A survey of school counselor interventions. Journal of Counselor Preparation and Supervision, 4, 24-40. doi:10.7729/42.0023

Coulter, D. (2002). What counts as action in educational action research? Educational Action Research, 10, 189-206. doi:10.1080/09650790200200181

Delgado, R., \& Stefancic, J. (2012). Critical race theory: An introduction (2nd ed.). New York: New York University Press.

Dessel, A., \& Rogge, M. E. (2008). Evaluation of intergroup dialogue: A review of the empirical literature. Conflict Resolution Quarterly, 26, 199-238. doi:10.1002/crq.230

Dessel, A., Rogge, M. E., \& Garlington, S. B. (2006). Using intergroup dialogue to promote social justice and change. Social Work, 51, 303-315. doi:10.1093/sw/51.4.303 
Journal for Social Action in Counseling and Psychology

Volume 9, Number 1, Summer 2017

Community Dialogues - Cook et al. 35

Elias, M. J., \& Haynes, N. M. (2008). Social competence, social support, and academic achievement in minority, low-income, urban elementary school children. School Psychology Quarterly, 23, 474. doi:10.1037/1045-3830.23.4.474

Ferlazzo, L. (2011). Involvement or engagement? Educational Leadership, 68(8), 10-14. Retrieved from http://www.ascd.org/publications/educational-leadership.aspx

Ferlazzo, L., \& Hammond, L. A. (2009). Building parent engagement in schools. Santa Barbara, CA: Linworth.

Glass, R. D., \& Newman, A. (2015). Ethical and epistemic dilemmas in knowledge production: Addressing their intersection in collaborative, community-based research. Theory and Research in Education, 13, 23-27. doi:10.1177/1477878515571178

González, R. L., \& Jackson, C. L. (2013). Engaging with parents: The relationship between school engagement efforts, social class, and learning. School Effectiveness and School Improvement, 24, 316-335. doi:10.1080/09243453.2012.680893

Hammack, P. L., \& Pilecki, A. (2015). Power in history: Contrasting theoretical approaches to intergroup dialogue. Journal of Social Issues, 71, 371-385. doi:10.1111/josi.12116

Hsieh, H. F., \& Shannon, S. E. (2005). Three approaches to qualitative content analysis. Qualitative Health Research, 15, 1277-1288. doi:10.1177/1049732305276687

Ippolito, J. (2010). In(formal) conversation with minority parents and communities of a Canadian Junior School: Findings and cautions from the Field. The School Community Journal, 20(1), 141-158. Retrieved from www.schoolcommunitynetwork.org/SCJ.aspx

Kvale, S., \& Brinkmann, S. (2009). Interviews: Learning the craft of qualitative research interviewing (2nd ed.). Thousand Oaks, CA: Sage Publications.

Lee, J., \& Shute, V. J. (2010). Personal and social-contextual factors in K-12 academic performance: An integrative perspective on student learning. Educational Psychologist, 45, 185-202. doi:10.1080/00461520.2010.493471

Lyons, H. Z., Bike, D. H., Ojeda, L., Johnson, A., Rosales, R., \& Flores, L. Y. (2013). Qualitative research as social justice practice with culturally diverse populations. Journal for Social Action in Counseling and Psychology, 5, 10-25. Retrieved from http://jsacp.tumblr.com/

Mellin, E. A., Belknap, E. E., Brodie, I. L., \& Sholes, K. (2015). Opening school doors to communities and families: A social capital perspective for multiparity collaboration. Journal for Social Action in Counseling and Psychology, 7, 1-18. Retrieved from 
Journal for Social Action in Counseling and Psychology

Volume 9, Number 1, Summer 2017

Community Dialogues - Cook et al. 36

http://jsacp.tumblr.com/

Miles, J. R., \& Kivlighan, D. J. (2012). Perceptions of group climate by social identity group in intergroup dialogue. Group Dynamics: Theory, Research, And Practice, 16(3), 189-205. doi:10.1037/a0028634

Mischen, P. A., \& Sinclair, T. A. P. (2009). Making implementation more democratic through action implementation research. Journal of Public Administration Research and Theory, 19, 145-164. doi:10.1093/jopart/mum040

Nagda, B., McCoy, M., \& Barrett, M. (2006). Mix it up: Crossing social boundaries as a pathway to youth civic engagement. National Civic Review, 95, 47-56. doi:10.1002/ncr.131

Price-Mitchell, M. (2009). Boundary dynamics: Implications for building parent-school partnerships. The School Community Journal, 19, 9-26. Retrieved from http://www.schoolcommunitynetwork.org/SCJ.aspx

Reece, C. A., Staudt, M., \& Ogle, A. (2013). Lessons learned from a neighborhood-based collaboration to increase parent engagement. School Community Journal, 23, 207-225. Retrieved from http://www.schoolcommunitynetwork.org/SCJ.aspx

Rush, S. E. (2011). Talking about race and equality. University Of Florida Journal Of Law \& Public Policy, 22, 417-429. Retrieved from http://www.ufjlpp.org/

Saldaña, J. (2013). The coding manual for qualitative researchers (2nd ed.). Thousand Oaks, CA: Sage Publications.

Schreier, M. (2012). Qualitative content analysis in practice. Thousand Oaks, CA: Sage Publications.

Solorzano, D. G. (1997). Images and words that wound: Critical Race Theory, racial stereotyping, and teacher education. Teacher Education Quarterly, 24, 5-15. Retrieved from http://www.jstor.org/stable/23478088

Steen, S., \& Noguera, P. S. (2010). A broader and bolder approach to school reform: Expanded partnership roles for school counselors. Professional School Counseling, 14, 42-52. doi:10.5330/prsc.14.1.puq62087h7q70801

Taylor, W. (2013, October 17). State education chief eyes level 5 status for Denver School. Dorchester Reporter, 30, 3. Retrieved from http://www.dotnews.com/REP\%204213web.pdf 
Journal for Social Action in Counseling and Psychology

Volume 9, Number 1, Summer 2017

Walsh, K. C. (2007). Talking about race. Community dialogues and the politics of difference. Chicago, IL: University of Chicago Press.

Yull, D., Blitz, L., Thompson, T., \& Murray, C. (2014). Can we talk? Using community-based participatory action research to build family and school partnerships with families of color. School Community Journal, 24, 9-31. Retrieved from http://www.schoolcommunitynetwork.org/SCJ.aspx

Zhang, D., Hsu, H., Kwok, O., Benz, M., \& Bowman-Perrott, L. (2011). The impact of basic-level parent engagements on student achievement: Patterns associated with race/ethnicity and socioeconomic status (SES). Journal of Disability Policy Studies, 22, 28-39. doi:10.1177/1044207310394447 